\title{
PNPLA3 rs738409 polymorphism in Patients with Type 2 Diabetes and Concomitant Liver Pathology in Yakutia
}

\author{
Khariton A. Kurtanov, $\mathrm{PhD}^{1}$; Nadezhda I. Pavlova, $\mathrm{PhD}^{1^{*}}$; Aleksandra T. Diakonova ${ }^{1}$; \\ Lyubovy A. Sydykova, $\mathrm{PhD}^{2}$; Sardana V. Markova, $\mathrm{PhD}^{2}$; Vladimir V. Dodokhov, $\mathrm{PhD}^{3}$ \\ ${ }^{I}$ Yakut Science Center of Complex Medical Problems \\ ${ }^{2}$ M. K. Ammosov North-Eastern Federal University; ${ }^{3} Y a k u t$ State Agricultural Academy \\ Yakutsk, the Republic of Sakha (Yakutia), Russia
}

\begin{abstract}
Background: The pathogenetic mechanisms of type 2 diabetes (T2D) and non-alcoholic fatty liver disease are closely related. Currently, multiple studies have demonstrated a link between the PNPLA3 148M variant and the development and progression of NAFLD, including liver fibrosis. The aim of our research was to study the distribution of alleles and genotypes of the PNPLA3 rs738409 SNP in Russians and Yakuts living in Yakutia, as well as to search for associations of the PNPLA3 rs738409 SNP in patients with T2D and non-alcoholic fatty liver disease / non-alcoholic steatohepatitis.

Methods and Results: The study included 179 patients (28 Russians and 151 Yakuts) with T2D and concomitant liver diseases of non-infectious origin. The comparison group consisted of 147 healthy volunteers of Russian ethnicity and 246 healthy volunteers of Yakut ethnicity. The PNPLA3 738409 SNP was analyzed by PCR-RFLP reaction. The results found a significant difference between the frequencies of the PNPLA3 rs738409 genotypes and alleles in Russians and Yakuts, both among healthy volunteers and in T2D patients with liver diseases. The frequency of the $\mathrm{G}$ allele occurrence in the group of healthy Yakuts was significantly higher (OR-3.313; 95\% CI: 2.444-4.499; $P<0.001$ ) than in the group of healthy Russians. No significant differences were found for the PNPLA3 rs 738409 genotype and allele frequencies among a healthy sample and a sample of T2D patients with non-alcoholic fatty liver disease / non-alcoholic steatohepatitis, both in the Russian and Yakut populations. (International Journal of Biomedicine. 2020;10(4):438-441.)
\end{abstract}

Key Words: Type 2 diabetes $\bullet$ non-alcoholic fatty liver disease $\bullet P N P L A 3 \bullet$ rs $738409 \bullet$ I148M

\section{Abbreviations}

NAFLD, non-alcoholic fatty liver disease; NASH, non-alcoholic steatohepatitis; PNPLA3, patatin-like phospholipase domaincontaining protein 3; PCR, polymerase chain reaction; RFLP, restriction fragment length polymorphism; SNP, single nucleotide polymorphism; T2D, type 2 diabetes.

\section{Introduction}

Type 2 diabetes (T2D) is one of the most socially significant pathologies in the Republic of Sakha (Yakutia). T2D often coexists with non-alcoholic fatty liver disease (NAFLD) ${ }^{(1)}$ which is considered the most common cause of chronic liver disease. ${ }^{(2)}$ The prevalence of NAFLD among

*Corresponding author: Nadezhda I. Pavlova, PhD. Yakut Science Center of Complex Medical Problems. Yakutsk, the Republic of Sakha (Yakutia), Russia.E-mail: solnishko 84@inbox.ru patients with $\mathrm{T} 2 \mathrm{DM}$ is $60 \%-80 \%$, and the incidence of NASH is $12 \%-40 \%{ }^{(3,4)}$ Since NAFLD is closely linked to metabolic syndrome, it is frequently recognized as the hepatic manifestation of the metabolic syndrome ${ }^{(5)}$ and constitutes the most frequent liver condition worldwide. ${ }^{(6,7)}$ The pathogenetic mechanisms of NAFLD and T2D are closely related. In combination, these diseases aggravate each other, significantly, increasing the likelihood of the patient developing liver fibrosis. Whether NAFLD is a consequence or cause of metabolic dysfunction is currently unknown. Early liver diseases occur with unexpressed symptoms or are asymptomatic; therefore, timely diagnosis and prevention of liver diseases, especially 
in patients with $\mathrm{T} 2 \mathrm{D}$, is necessary. The study of the molecular genetic mechanism of the pathogenesis of NAFLD will help in the search for new biomarkers of the disease. ${ }^{(4)}$

PNPLA3, also known as adiponutrin, which is found in hepatocytes and adipocytes, is one of the candidates potentially related to NAFLD susceptibility. ${ }^{(8,9)}$ PNPLA3 hydrolyses triglycerides and retinyl esters ${ }^{(10)}$ and is associated with NAFLD in GWAS. ${ }^{(1)}$ In 2008, Romeo et al. ${ }^{(11)}$ reported that an allele in PNPLA3 (rs738409[G], encoding I148M) was strongly associated with increased hepatic fat levels $\left(P=5.9 \times 10^{-10}\right)$ and with hepatic inflammation $\left(P=3.7 \times 10^{-4}\right)$. Currently, multiple studies have demonstrated a link between the PNPLA3 $148 \mathrm{M}$ variant and the development and progression of NAFLD, including liver fibrosis. ${ }^{(12-17)}$

The aim of our research was to study the distribution of alleles and genotypes of the PNPLA3 rs738409 SNP in Russians and Yakuts living in Yakutia, as well as to search for associations of the PNPLA3 rs738409 SNP in patients with T2D and NAFLD/NASH.

\section{Materials and Methods}

The study of the PNPLA3 SNPs (rs2294918 and rs738409) was carried out in the Department of Molecular Genetics at YSC CMP. For the study, we used DNA samples from the collection of biomaterials of the YSC CMP (Project "The Genome of Yakutia"; No. USE_507512). The study included 179 patients (28 Russians and 151 Yakuts) with T2D and concomitant liver diseases of non-infectious origin. Exclusion criteria: autoimmune hepatitis, primary biliary cholangitis, primary sclerosing cholangitis, hereditary hemochromatosis, Wilson-Konovalov disease, and alcohol abuse $(>30 \mathrm{~g} / \mathrm{l})$. The comparison group consisted of 147 healthy volunteers of Russian ethnicity and 246 healthy volunteers of Yakut ethnicity. The biomaterial was collected during expeditions conducted in the Central regions of Yakutia. Ethnicity was taken into account up to the third generation.

Genomic DNA was isolated using the standard phenolchloroform extraction method from frozen whole blood. After DNA extraction, the samples were subjected to a PCR-RFLP reaction to analyze the PNPLA3 rs 738409 SNP.

The conditions for the amplification of the region of the gene containing the polymorphic variant, indicating the sequence of oligonucleotide primers, the restriction enzyme used and the lengths of the restoration fragments, are presented in Table 1.

Table 1.

Conditions for PCR-RFLP analysis

\begin{tabular}{|c|c|c|c|c|}
\hline Primer & $\begin{array}{l}\text { Annealing } \\
\text { temperature }\end{array}$ & $\begin{array}{c}\text { Length of } \\
\text { amplicate, } \\
\text { bp }\end{array}$ & $\begin{array}{c}\text { Restriction } \\
\text { enzyme }\end{array}$ & $\begin{array}{l}\text { Restriction } \\
\text { fragment } \\
\text { length, bp }\end{array}$ \\
\hline $\begin{array}{l}\text { F: 5'-TGGGCCTGA } \\
\text { AGTCCGAGGGT-3' }\end{array}$ & \multirow{2}{*}{$66^{\circ} \mathrm{C}$} & \multirow{2}{*}{333 bp } & \multirow{2}{*}{ BstF5 I } & \multirow{2}{*}{$\begin{array}{c}\mathrm{CC}-200 \\
133 \\
\mathrm{CG}-333 \\
200,133 \\
\mathrm{GG}-333\end{array}$} \\
\hline $\begin{array}{l}\text { R: 5'- CCGACACCA } \\
\text { GTGCCCTGCAG-3' }\end{array}$ & & & & \\
\hline
\end{tabular}

bp-base pairs
Genotypes were determined by analyzing the sizes of the resulting fragments by gel electrophoresis on $4 \%$ agarose gel with ethidium bromide in standard Tris-acetate buffer at $120 \mathrm{~V}$ for 1 hour. Restriction products were visualized using a gel documentation system in a Vilber Lourmat Compact UV Transilluminator (France) (Fig.1).

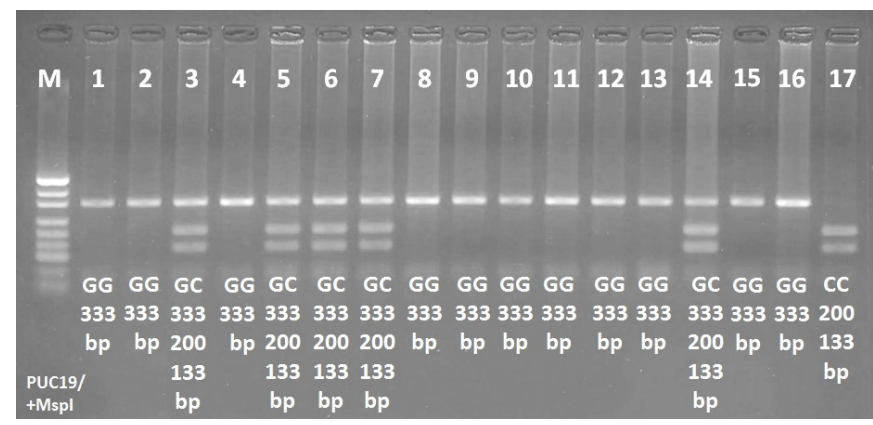

Fig. 1. PCR-RFLP analysis of PNPLA3 gene (rs738409) C>G genotypes with restriction endonuclease enzyme BstF5 I.

The study was approved by the Ethics Committee of the Yakut Science Center of Complex Medical Problems (YSC CMP). Written informed consent was obtained from each research participant (or the participant's parent/guardian).

Statistical analysis was performed using the Statistica 8.0 software package (Stat-Soft Inc., USA). The correspondence of the distributions of genotypes to the expected values at HWE and comparison of the frequencies of allelic variants/ genotypes were performed using the chi-square test. Odds ratios (ORs) and 95\% confidence intervals (CIs) were calculated. A probability value of $P<0.05$ was considered statistically significant.

\section{Results and Discussion}

An analysis of the frequency distribution of alleles and genotypes of the PNPLA3 rs738409 SNP in the studied samples showed a difference between Yakuts and Russians, both in healthy volunteers and among those suffering from liver diseases (Table 2).

Table 2

The frequency distribution of alleles and genotypes of the PNPLA3 rs738409 SNP in Russians and Yakuts

\begin{tabular}{|c|c|c|c|c|c|c|c|c|c|}
\hline \multirow[t]{2}{*}{ Samples } & \multirow[t]{2}{*}{$\mathrm{n}$} & \multirow{2}{*}{$\begin{array}{l}\text { Divi- } \\
\text { sion }\end{array}$} & \multicolumn{3}{|c|}{$\begin{array}{c}\text { Genotype } \\
\text { frequency, } \%\end{array}$} & \multicolumn{2}{|c|}{$\begin{array}{c}\text { Allele } \\
\text { frequency }\end{array}$} & \multirow{2}{*}{$\chi^{2}$} & \multirow[t]{2}{*}{$P$} \\
\hline & & & $\mathrm{CC}$ & $\mathrm{CG}$ & GG & $\mathrm{C}$ & $\mathrm{G}$ & & \\
\hline \multirow{2}{*}{$\begin{array}{l}\text { Population } \\
\text { sample of the } \\
\text { Yakuts }\end{array}$} & \multirow{2}{*}{246} & $\mathrm{O}$ & 13.8 & 26.4 & 59.8 & \multirow{2}{*}{0.270} & \multirow{2}{*}{0.730} & \multirow[b]{2}{*}{26.825} & \multirow[b]{2}{*}{0.000} \\
\hline & & $\mathrm{E}$ & 7.3 & 39.4 & 53.2 & & & & \\
\hline \multirow{2}{*}{$\begin{array}{l}\text { Population } \\
\text { sample of } \\
\text { Russians }\end{array}$} & \multirow[b]{2}{*}{147} & $\mathrm{O}$ & 41.5 & 27.2 & 31.3 & \multirow[b]{2}{*}{0.551} & \multirow[b]{2}{*}{0.449} & \multirow[b]{2}{*}{29.77} & \multirow[b]{2}{*}{0.00} \\
\hline & & $\mathrm{E}$ & 30.4 & 49.5 & 20.2 & & & & \\
\hline \multirow{2}{*}{$\begin{array}{l}\text { A sample of } \\
\text { Yakut patients }\end{array}$} & \multirow{2}{*}{151} & $\mathrm{O}$ & 9.9 & 29.8 & 60.3 & \multirow{2}{*}{0.248} & \multirow{2}{*}{0.752} & \multirow{2}{*}{6.147} & \multirow{2}{*}{0.013} \\
\hline & & $\mathrm{E}$ & 6.2 & 37.3 & 56.5 & & & & \\
\hline \multirow{2}{*}{$\begin{array}{l}\text { A sample of } \\
\text { Russian patients }\end{array}$} & \multirow{2}{*}{28} & $\mathrm{O}$ & 35.7 & 25.0 & 39.3 & \multirow{2}{*}{0.482} & \multirow{2}{*}{0.518} & \multirow{2}{*}{6.982} & \multirow{2}{*}{0.008} \\
\hline & & E & 23.2 & 49.9 & 26.8 & & & & \\
\hline
\end{tabular}

$O$-Observed; E-Expected 
The sample of healthy patients of Russian ethnicity had the largest number of carriers of the homozygous CC genotype, while the samples of patients with T2D were dominated by carriers of the homozygous GG genotype. Among patients with T2D and a sample of healthy Yakut ethnicity, the largest number was carriers of the GG genotype.

We found significant differences between the frequencies of the PNPLA3 rs738409 genotypes and alleles in healthy volunteers of Yakut and Russian ethnic groups (Table $3)$. The frequency of the $\mathrm{C}$ allele and the $\mathrm{CC}$ homozygous genotype prevailed in the sample of healthy volunteers of Russian ethnicity, while the frequency of the $G$ allele and the homozygous GG genotype prevailed in the sample of healthy volunteers of Yakut ethnicity. The calculation of the odds ratio showed that the frequency of occurrence of the $G$ allele in the Yakut group was significantly higher $(\mathrm{OR}=3.313 ; 95 \% \mathrm{CI}$ : 2.444-4.499; $P<0.001$ ) than in the sample of Russian ethnicity.

\section{Table 3.}

The frequency distribution of alleles and genotypes of the PNPLA3 rs738409 SNP among healthy volunteers of Yakut and Russian ethnic groups

\begin{tabular}{|c|c|c|c|c|c|}
\hline $\begin{array}{c}\text { Genotype/ } \\
\text { allele }\end{array}$ & $\begin{array}{l}\text { Yakuts } \\
(\mathrm{n}=246)\end{array}$ & $\begin{array}{l}\text { Russians } \\
(\mathrm{n}=147)\end{array}$ & $\chi^{2}$ & $\begin{array}{c}\text { OR } \\
(95 \% \mathrm{CI})\end{array}$ & $P$-value \\
\hline $\mathrm{C} / \mathrm{C}$ & $34(13.8 \%)$ & $61(41.5 \%)$ & \multirow{3}{*}{44.357} & \multirow{5}{*}{$\begin{array}{c}3.313 \\
(2.444- \\
4.499)\end{array}$} & \multirow{3}{*}{$0.000^{*}$} \\
\hline $\mathrm{C} / \mathrm{G}$ & $65(26.4 \%)$ & $40(27.2 \%)$ & & & \\
\hline $\mathrm{G} / \mathrm{G}$ & $147(59.8 \%)$ & $46(31.3 \%)$ & & & \\
\hline $\mathrm{C}$ & 0.270 & 0.551 & \multirow{2}{*}{60.653} & & \multirow{2}{*}{$0.000^{* *}$} \\
\hline G & 0.730 & 0.449 & & & \\
\hline
\end{tabular}

$P$ - the achieved level of significance in comparing the distribution of genotypes $(*)$ and allele frequency $(* *)$

We found no significant differences in the frequency distribution of the PNPLA3 rs738409 genotypes and alleles among healthy Russians and Russian T2D patients with concomitant liver diseases (Table 4). In the sample of T2D patients of Russian ethnicity with concomitant liver pathologies, the homozygous GG genotype prevailed, which is probably due to the small number of samples $(n=28)$. The homozygous CC genotype prevailed among the sample of healthy volunteers of Russian ethnicity.

We found no significant differences in the frequency distribution of genotypes and alleles among healthy Yakuts and Yakut T2D patients with concomitant liver diseases (Table 5). According to the open-source data of the 1000 Genomes project, ${ }^{(18)}$ the PNPLA3 rs $2294918 \mathrm{G}$ allele is found with a high frequency in populations of Central and South America (Peruvians - 71.8\%, Mexicans - 55.5\%, Colombians - 41\%). Attention is drawn to the fact that the higher the frequency of the $\mathrm{G}$ allele, the higher the percentage of indigenous people in the population. For example, in the population of Puerto Rico, where the Native American population is $11 \%$, the frequency of the $\mathrm{G}$ allele is $31.7 \%$. In Europeans, the frequency of the $\mathrm{G}$ allele is on average $22.6 \%$. Among Asians, the Japanese have a high frequency of the $\mathrm{G}$ allele $(42.3 \%)$. The owners of the lowest frequency of the $\mathrm{G}$ allele are Africans (8.6\%-17.2\%).
Table 4.

The frequency distribution of alleles and genotypes of the PNPLA3 rs 738409 SNP among healthy Russians and Russian T2D patients with concomitant liver diseases

\begin{tabular}{|c|c|c|c|c|c|}
\hline $\begin{array}{c}\text { Genotype } / \\
\text { allele }\end{array}$ & $\begin{array}{c}\text { Patients } \\
(\mathrm{n}=28)\end{array}$ & $\begin{array}{c}\text { Control sample } \\
(\mathrm{n}=147)\end{array}$ & $\chi^{2}$ & $\begin{array}{c}\text { OR } \\
(95 \% \mathrm{CI})\end{array}$ & $P$-value \\
\cline { 1 - 3 } $\mathrm{C} / \mathrm{C}$ & $10(35.7 \%)$ & $61(41.5 \%)$ & & & \\
\cline { 1 - 3 } $\mathrm{C} / \mathrm{G}$ & $7(25 \%)$ & $40(27.2 \%)$ & 0.698 & & $0.705^{*}$ \\
\cline { 1 - 3 } $\mathrm{G} / \mathrm{G}$ & $11(39.3 \%)$ & $46(31.3 \%)$ & & $\begin{array}{c}(0.744- \\
2.336)\end{array}$ & \\
\cline { 1 - 3 } $\mathrm{C}$ & 0.482 & 0.551 & \multirow{2}{*}{0.643} & & $0.423^{* *}$ \\
\cline { 1 - 3 } $\mathrm{G}$ & 0.518 & 0.449 & & & \\
\hline
\end{tabular}

$P$-the achieved level of significance in comparing the distribution of genotypes $\left({ }^{*}\right)$ and allele frequency $\left({ }^{* *}\right)$

Table 5.

The frequency distribution of alleles and genotypes of the PNPLA3 rs 738409 SNP among healthy Yakuts and Yakut T2D patients with concomitant liver diseases

\begin{tabular}{|c|c|c|c|c|c|}
\hline $\begin{array}{c}\text { Genotype } / \\
\text { allele }\end{array}$ & $\begin{array}{c}\text { Patients } \\
(\mathrm{n}=151)\end{array}$ & $\begin{array}{c}\text { Control sample } \\
(\mathrm{n}=246)\end{array}$ & $\chi^{2}$ & $\begin{array}{c}\text { OR } \\
(95 \% \mathrm{CI})\end{array}$ & $P$-value \\
\hline $\mathrm{C} / \mathrm{C}$ & $15(9.9)$ & $34(13.8)$ & & & \multirow{2}{*}{$0.464^{*}$} \\
\cline { 1 - 3 } $\mathrm{C} / \mathrm{G}$ & $45(29.8)$ & $65(26.4)$ & 1.535 & & \\
\cline { 1 - 3 } $\mathrm{G} / \mathrm{G}$ & $91(60.3)$ & $147(59.8)$ & & $(0.808-1.557)$ & \\
\cline { 1 - 3 } $\mathrm{C}$ & 0.248 & 0.270 & \multirow{2}{*}{0.361} & & $0.548^{* *}$ \\
\hline $\mathrm{G}$ & 0.752 & 0.730 & & & \\
\hline
\end{tabular}

$P$ - the achieved level of significance in comparing the distribution of genotypes $\left({ }^{*}\right)$ and allele frequency $\left(^{* *}\right)$

In conclusion, our study found a significant difference between the frequencies of the PNPLA3 rs2294918 genotypes and alleles in Russians and Yakuts, both among healthy volunteers and in T2D patients with liver diseases. The frequency of the $\mathrm{G}$ allele occurrence in the group of healthy Yakuts was significantly higher ( $\mathrm{OR}=3.313 ; 95 \% \mathrm{CI}$ : 2.444 4.499; $P<0.001)$ than in the group of healthy Russians. No significant differences were found for the PNPLA3 rs2294918 genotype and allele frequencies among a healthy sample and a sample of T2D patients with NAFLD/NASH, both in the Russian and Yakut populations.

\section{Competing Interests}

The authors declare that they have no competing interests.

\section{Sources of Funding}

The study was carried out within the framework of the project "The study of the genetic structure and burden of hereditary pathology of populations of the Republic of Sakha (Yakutia), using the Unique scientific equipment (USE) "The Genome of Yakutia" (Reg. No. USU_507512).

\section{References}

1. Birjukova EV, Rodionova S.V. [Type 2 diabetes and non- 
alcoholic fatty liver disease are modern diseases]. Medical almanac. 2017;6 (51):130-135. [Article in Russian].

2. Targher G, Byrne CD. Clinical Review: Nonalcoholic fatty liver disease: a novel cardiometabolic risk factor for type 2 diabetes and its complications. J Clin Endocrinol Metab. 2013 Feb;98(2):483-95. doi: 10.1210/jc.2012-3093.

3. Petunina NA, Tel'nova MJe. [Non-alcoholic fatty liver disease]. Medical Council. 2016;4:92-95. [Article in Russian]. 4. Sharonova LA, Verbovoj AF, Verbovaja NI, Pashenceva AV. [Relationship between non-alcoholic fatty liver disease and type 2 diabetes]. Russian Medical Journal. 2017;22:16351640.5. [Article in Russian].

5. Buzzetti E, Pinzani M, Tsochatzis EA. The multiple-hit pathogenesis of non-alcoholic fatty liver disease (NAFLD). Metabolism. 2016 Aug;65(8):1038-48. doi: 10.1016/j. metabol.2015.12.012.

6. Leoni S, Tovoli F, Napoli L, Serio I, Ferri S, Bolondi L. Current guidelines for the management of non-alcoholic fatty liver disease: A systematic review with comparative analysis. World J Gastroenterol. 2018 Aug 14;24(30):3361-3373. doi: 10.3748/wjg.v24.i30.3361.

7. Marjot T, Moolla A, Cobbold JF, Hodson L, Tomlinson JW. Nonalcoholic Fatty Liver Disease in Adults: Current Concepts in Etiology, Outcomes, and Management. Endocr Rev. 2020 Jan 1;41(1):bnz009. doi: 10.1210/endrev/bnz009. 8. Wilson PA, Gardner SD, Lambie NM, Commans SA, Crowther DJ. Characterization of the human patatin-like phospholipase family. J Lipid Res. 2006 Sep;47(9):1940-9. doi: 10.1194/jlr.M600185-JLR200.

9. Kotronen A, Johansson LE, Johansson LM, Roos C, Westerbacka J, Hamsten A, Bergholm R, Arkkila P, Arola J, Kiviluoto T, Fisher RM, Ehrenborg E, Orho-Melander M, Ridderstråle M, Groop L, Yki-Järvinen H. A common variant in PNPLA3, which encodes adiponutrin, is associated with liver fat content in humans. Diabetologia. 2009 Jun;52(6):1056-60. doi: 10.1007/s00125-009-1285-z.

10. Huang Y, Cohen JC, Hobbs HH. Expression and characterization of a PNPLA3 protein isoform (I148M) associated with nonalcoholic fatty liver disease. J Biol Chem. 2011 Oct 28;286(43):37085-93. doi: 10.1074/jbc. M111.290114.

11. Romeo S, Kozlitina J, Xing C, Pertsemlidis A, Cox D, Pennacchio LA, Boerwinkle E, Cohen JC, Hobbs HH. Genetic variation in PNPLA3 confers susceptibility to nonalcoholic fatty liver disease. Nat Genet. 2008 Dec;40(12):1461-5. doi: 10.1038/ng.257.

12. Rotman Y, Koh C, Zmuda JM, Kleiner DE, Liang TJ; NASH CRN. The association of genetic variability in patatinlike phospholipase domain-containing protein 3 (PNPLA3) with histological severity of nonalcoholic fatty liver disease. Hepatology. 2010 Sep;52(3):894-903. doi: 10.1002/hep.23759. 13. Sookoian S, Pirola CJ. Meta-analysis of the influence of I148M variant of patatin-like phospholipase domain containing 3 gene (PNPLA3) on the susceptibility and histological severity of nonalcoholic fatty liver disease. Hepatology. 2011 Jun;53(6):1883-94. doi: 10.1002/hep.24283.

14. Krawczyk M, Grünhage F, Zimmer V, Lammert F. Variant adiponutrin (PNPLA3) represents a common fibrosis risk gene: non-invasive elastography-based study in chronic liver disease. J Hepatol. 2011 Aug;55(2):299-306. doi: 10.1016/j. jhep.2010.10.042.

15. Zain SM, Mohamed R, Mahadeva S, Cheah PL, Rampal S, Basu RC, Mohamed Z. A multi-ethnic study of a PNPLA3 gene variant and its association with disease severity in nonalcoholic fatty liver disease. Hum Genet. 2012 Jul;131(7):114552. doi: 10.1007/s00439-012-1141-y.

16. Dongiovanni P, Donati B, Fares R, Lombardi R, Mancina RM, Romeo S, Valenti L. PNPLA3 I148M polymorphism and progressive liver disease. World J Gastroenterol. 2013 Nov 7;19(41):6969-78. doi: 10.3748/wjg.v19.i41.6969.

17. Chandrasekharan K, Alazawi W. Genetics of NonAlcoholic Fatty Liver and Cardiovascular Disease: Implications for Therapy? Front Pharmacol. 2020 Jan 8;10:1413. doi: 10.3389/fphar.2019.01413.

18. GSR and the 1000 Genomes Project [Internet]. Available from: https://www.internationalgenome.org/ 